\title{
PENGARUH VARIABEL MAKRO EKONOMI TERHADAP PROFITABILITAS BANK SYARIAH DI INDONESIA PERIODE $2009-2014$
}

\author{
Amirus Sodiq \\ Sekolah Tinggi Agama Islam Negeri Kudus \\ Amirus_sodiq@yahoo.co.id
}

\begin{abstract}
This research aims to explain the influence analysis of Inflation, Gross Domestic Bruto, and Interest Rate to the Return on Asset (ROA) of Islamic Banking period 2009-2014. The sampling technique used is purposive sampling. This research sample gained from three Islamic banks and the data were obtained from published financial statement of Bank of Indonesia. Data analysis technique used multiple linier regression analysis. Where previously data had been tested with the classical assumption include data normality test, heteroscedasticity, multicollinearity and autocorrelation. F Test result showed that simultaneous variable of Inflation, Gross Domestic Bruto, and Interest Rate have a significant effect on ROA while T Test result showed that partially Inflation haven't a significant effect on ROA while GDP have a positive and significant effect on ROA while Interest Rate have a significant effect on ROA.
\end{abstract}

KEY WORDS: Profitabilitas, PDB, Inflasi, Suku Bunga

\section{A. PENDAHULUAN}

Perlambatan ekonomi yang terjadi di Indonesia pada 2015 ini diklaim oleh Menkeu Bambang Brodjonegoro sebagai akibat adanya tekanan global imbas memburuknya ekonomi Cina setelah berjaya selama dua dekade terakhir. Selain itu, kondisi ekonomi Amerika Serikat yang telah membaik sehingga nilai tukar dolar, khususnya terhadap rupiah, kian menguat (Irfany, 2015).

Sedangkan Gubernur Bank Indonesia Agus Martowardojo mengatakan bahwa makro ekonomi Indonesia masih terbilang baik, di mana angka inflasi yang bertengger di 0,93 persen dan defisit transaksi berjalan yang menurun ke 2,3 persen adalah sentimen bagus untuk fundamental ekonomi tanah air. "Neraca 
perdagangan juga mengalami surplus".

Agus juga menjelaskan bahwa depresiasi rupiah masih lebih baik bila dibandingkan negara berkembang lain. Secara tahunan, depresiasi rupiah memang mencapai 8 persen. Namun, secara month to date, depresiasi hanya 1 persen, sementara negara-negara ASEAN mencapai lebih dari 1,5 persen. Selain itu, volatilitas rupiah juga dianggap membaik karena berada pada kisaran 8 persen. Sedangkan negara lain, seperti Turki dan Afrika Selatan saja, mencapai 10 persen.

Hingga pertengahan 2015, pertumbuhan perbankan syariah di Indonesia telah mengalami perkembangan yang cukup signifikan, dimana volume usaha bank umum syariah telah mencapai Rp. 272,4 Triliun, sedangkan volume usaha bank pembiayaan rakyat syariah mencapai Rp. 6,8 Triliun, atau secara keseluruhan volume usaha perbankan syariah telah mencapai Rp. 279,2 Triliun, dengan kata lain mengalami peningkatan sebesar 8,3\% (yoy) dibanding volume usaha tahun 2014 yang mencapai Rp. 257,8 Triliun (SPS Juni 2015).

Seiring dengan melambatnya pertumbuhan ekonomi Indonesia pada tahun 2015, pertumbuhan perbankan syariahjuga mengalami perlambatan khususnya dalam hal NPFnya, bahkan sebaliknya industri perbankan syariah mulai dihantui dengan peningkatan pembiayaan macet (Non Performing Financing), dimana rasio NPF perbankan syariah pada pertengahan 2015 mencapai $4,7 \%$ atau mengalami peningkatan sebesar 0,83\% dibanding rasio NPF pada semester pertama tahun 2014 yang sebesar 3,9\%, peningkatan ini dianggap sangat tajam karena sudah mendekati ambang batas (level maksimum) yaitu 5\% (Bachdar, 2015).

Dari segi kelembagaan, jumlah bank umum syariah pada pertengahan 2015 berjumlah 12 bank atau bertambah 1 bank dibanding tahun 2014, sedangkan Unit Usaha Syariah berkurang satu dibanding tahun sebelumnya, jumlah bank pembiayaan rakyat syariah juga mengalami penurunan sebanyak 2 bank dibanding tahun sebelumnya, namun jumlah kantor BPRS mengalami penambahan 4 bank, penambahan jumlah kantor BPRS di daerah tentu akan menambah pembiayaan yang dikeluarkan BPRS yang akan berdampak pada peningkatan pendapatan bank, hal tersebut bisa dilihat pada tabel berikut ini 
Pengaruh Variabel Makro Ekonomi terhadap Profitabilitas ...

Tabel 1.

Perkembangan Jaringan Kantor Bank Syariah

\begin{tabular}{|l|c|c|}
\hline Kelompok Bank & $\mathbf{2 0 1 4}$ & $\mathbf{2 0 1 5}$ \\
\hline Bank Umum Syariah & 11 & 12 \\
\hline Unit Usaha Syariah & 23 & 22 \\
\hline Jumlah Kantor BUS dan UUS & 2575 & 2468 \\
\hline BPRS & 163 & 161 \\
\hline Jumlah Kantor BPRS & 429 & 433 \\
\hline
\end{tabular}

Sumber: SPS Juni 2015 data diolah

Pada kuartal I tahun 2015, market share yang dicapai oleh perbankan syariah telah mengalami penurunan dari 4,86\% di tahun 2014 menjadi 4,6\%, jika di analisis ada beberapa faktor yang menyebabkan penurunan tersebut, di antaranya adalah terkoreksinya asset pembiayaan syariah sebesar 20,97\% (yoy), pada kuartal I tahun 2015 pembiayaan bank syariah mencapai Rp. 19,63 triliun padahal sebelumnya mampu mencapai Rp. 24,84 triliun.

Trend serupa juga terjadi pada laba perbankan syariah, dimana pada kuartal I tahun 2014 laba periode berjalan pembiayaan syariah mencapai Rp1,16 triliun, sedangkan pada akhir Maret 2015 laba pembiayaan hanya mencapai Rp136 miliar. Di saat yang sama pembiayaan jenis murabahah turun sebesar 22,17\% (yoy) dari Rp. 19,39 triliun pada kuartai I tahun 2014 menjadi Rp. 15,09 triliun pada kuartal I tahun ini.

Kondisi serupa juga terjadi pada pembiayaan ijarah, meskipun hanya terkoreksi tipis 3,45\% (yoy), dimana pada kuartal I 2014 mencapai Rp. 199,91 miliar dan menurun menjadi Rp. 193 miliar pada triwulan I 2015. Berbeda dengan piutang IMBT yang mengalami kenaikan sebesar 20,12\% (yoy) dari sebelumnya Rp. 1,54 triliun menjadi Rp. 1,85 triliun per Maret 2015. Ada pula piutang hiwalah yang berkontribusi sebesar Rp. 2 miliar, jenis pembiayaan tersebut hadir ke dalam industri sejak April 2014 lalu dengan capaian Rp. 2,85 miliar.

Dana pihak ketiga yang dihimpun BUS dan UUS pada semester pertama tahun 2015 tercatat tumbuh sebesar 12,4\% (yoy), sedangkan pada BPRS mencapai 13,9\%. Berdasarkan jenis instrumen, pertumbuhan terendah dialami deposito $(9,1 \%$, 
yoy) yang terjadi pada kelompok BUS. Sementara rekening giro merupakan instrument yang mengalami pertumbuhan paling tinggi yaitu sebesar $35 \%$, sedangkan rekening deposito pada BPRS merupakan instrument yang paling tinggi pertumbuhannya yaitu sebesar 14,1\% namun tidak berbeda jauh dengan rekening tabungan yang pertumbuhannya paling rendah yaitu sebesar $13,4 \%$ karena hanya selisih $0,7 \%$, hal tersebut dapat dilihat tabel di bawah ini

Tabel 2.

\section{Perkembangan DPK Semester 1 (2015)}

\begin{tabular}{|l|c|c|c|c|}
\hline Kelompok Bank & Giro & Tabungan & Deposito & DPK \\
\hline BUS dan UUS & & & & \\
\hline Nominal (Rp, triliun) & 23,3 & 62,1 & 129,9 & 215,3 \\
\hline Pertumbuhan (yoy) & $35 \%$ & $12,6 \%$ & $9,1 \%$ & $12,4 \%$ \\
\hline BPRS & & & & \\
\hline Nominal (Rp, triliun) & & 1,5 & 2,6 & 4,1 \\
\hline Pertumbuhan (yoy) & & $13,4 \%$ & $14,1 \%$ & $13,9 \%$ \\
\hline
\end{tabular}

Sumber: SPS Juni 2015 data diolah

Kinerja keuangan bank merupakan gambaran kondisi keuangan bank pada suatu periode tertentu baik mencakup aspek penghimpunan dana maupun penyaluran dananya. Kepercayaan dan loyalitas pemilik dana terhadap bank merupakan faktor yang sangat membantu dan mempermudah pihak manajemen bank untuk menyusun strategi bisnis yang baik. Sebaliknya para pemilik dana yang kurang menaruh kepercayaan kepada bank yang bersangkutan maka loyalitasnya pun sangat tipis, hal ini sangat tidak menguntungkan bagi bank yang bersangkutan karena para pemilik dana sewaktu-waktu dapat menarik dananya dan memindahkannya ke bank lain.

Penelitian ini bertujuan untuk menganalisis pengaruh variable makro ekonomi terhadap profitabilitas bank syariah di Indonesia, pada penelitian ini variable makro ekonomi direpresentasikan oleh pendapatan nasional yang diproksikan dengan produk domestic bruto, inflasi dan Tingkat suku bunga, sedangkan profitabilitas diproksikan dengan return on asset.

Penelitian ini menjadi penting dilakukan karena ditujukan untuk menganalisis pengaruh variable makro ekonomi 
terhadap profitabilitas bank syariah di Indonesia selama periode 2009 - 2014, sehingga manajemen bank syariah dapat menentukan kebijakan yang tepat terkait perubahan kebijakan makro ekonomi yang bisa terjadi secara perlahan-lahan maupun secara drastic, selain itu manajemen bank syariah juga dapat melakukan tindakan antisipatif untuk mengendalikan risiko yang ditimbulkan akibat adanya perubahan kebijakan mankro ekonomi.

\section{B. PEMBAHASAN}

Penelitian tentang pengaruh variable makro ekonomi terhadap profitabilitas bank syariah telah banyak dilakukan oleh peneliti-peneliti sebelumnya, di antaranya Haron (1996) dengan penelitiannya yang berjudul "Determinants of Islamic Bank Profitability". Di mana hasil penelitiannya menunjukkan bahwa variabel suku bunga berpengaruh negatif dan signifikan terhadap profitabilitas bank syariah, jumlah uang beredar (Money Supply) berpengaruh positif dan signifikan terhadap profitabilitas bank syariah, sedangkan variabel market place, market share, inflasi dan ukuran perusahaan tidak berpengaruh terhadap profitabilitas bank syariah.

Dalam peneitian yang berjudul "Determinants of profitability and rates of return margins in Islamic banks: some evidence from the Middle East" tentang pengaruh perpajakan, kondisi makro ekonomi, dan struktur pasar keuangan terhadap profitabilitas bank syariah yang dilakukan Bashir (2000) pada bank-bank syariah di delapan negara timur tengah, disimpulkan bahwa perpajakan berpengaruh negatif terhadap profitabilitas bank syariah, variabel kondisi makro ekonomi berpengaruh positif terhadap profitabilitas bank syariah sedangkan pasar modal dan bank merupakan dua variabel yang saling melengkapi.

Sedangkan Naceur (2003) yang melakukan penelitian dengan judul "The Determinants of The Tunisian Banking Industry Profitability: Panel Evidence", yaitu tentang pengaruh indikator makro ekonomi terhadap profitabilitas bank di Tunisia periode 1998-2000 menyimpulkan bahwa indikator makro ekonomi dalam hal ini inflasi dan tingkat pertumbuhan tidak berpengaruh terhadap profitabilitas bank, ukuran perusahaan berpengaruh negative signifikan terhadap Net Interest margin, 
sedangkan factor internal lainnya berpengaruh signifikan terhadap Net Interest margin.

Srairi (2009) melakukan penelitian dengan judul "Factor Influencing the Profitability of Conventional and Islamic Commercial Banks in GCC Countries" penelitian tersebut menggunakan ROAA (the return on average total assets of the banks) sebagai proksi profitabilitas. Hasil penelitiannya menunjukkan bahwa variabel inflasi tidak berpengaruh terhadap profitabilitas bank syariah dan bank konvensional. Variabel pendapatan nasional berpengaruh positif signifikan terhadap terhadap profitabilitas bank syariah dan bank konvensional. Sedangkan variabel jumlah uang yang beredar berpengaruh positif signifikan terhadap terhadap profitabilitas bank syariah dan bank konvensional.

Zeitun (2012) juga melakukan penelitian dengan judul “ Determinants of Islamic and Conventional Banks Performance in GCC Countries Using Panel Data Analysis" dengan mengambil sampel 38 bank konvensional dan 13 bank syariah selama periode 2002-2009, dengan menghasilkan kesimpulkan bahwa produk domestic bruto mempunyai korelasi positif dengan profitabilitas bank, inflasi mempunyai korelasi negative dengan profitabilitas bank sedangkan pertumbuhan bank dan kepemilikan asing tidak berpengaruh terhadap performa bank.

Sedangkan peneliti Indonesia yang melakukan penelitian tentang pengaruh variable makro ekonomi terhadap profitabilitas bank di antaranya adalah Fauziah (2011) melakukan penelitian tentang pengaruh inflasi terhadap profitabilitas bank muamalat Indonesia dan bank central Asia tahun 2007-2011 dan hasilnya Tidak terdapat pengaruh antara Inflasi terhadap ROA, ROE, dan BOPO pada Bank Muamalat Indonesia Maupun Bank Central Asia. Sedangkan penelitian Sahara (2013) tentang pengaruh inflasi, suku bunga BI, dan produk domestik bruto terhadap return on asset (roa) bank syariah di indonesia menyimpulkan bahwa inflasi dan PDB berpengaruh positif dan signifikan terhadap ROA sedangkan suku bunga BI berpengaruh negatif dan signifikan terhadap ROA.

Stiawan (2009) yang melakukan penelitian tentang pengaruh faktor makroekonomi, pangsa pasar dan karakteristik bank terhadap profitabilitas bank syariah (studi pada bank 
syariah periode 2005 - 2008) menyimpulkan bahwa variabel pertumbuhan inflasi dan pertumbuhan PDB tidak menunjukkan pengaruh signifikan terhadap ROA. Variabel FDR, pangsa pasar, CAR berpengaruh positif signifikan terhadap ROA, sedangkanvariabel NPF, BOPO, dan SIZE berpengaruh negatif signifikan terhadap ROA.

Sedangkan Anto dan Wibowo (2012) menyimpulkan dalam penelitiannya bahwa Secara bersama-sama variabel independen yang terdiri dari pendapatan nasional,inflasi, tingkat suku bunga, pangsa pasar dan jumlah uang yang beredar mempunyai pengaruh yang signifikan terhadap profitabilitas bank syariah yang diproksikan dengan return on equity (ROE). Secara parsial hanya variabel tingkat suku bunga yang berpengaruh negatif terhadap profitabilitas bank umum syariah secara signifikan. Sedangkan variabel lainnya tidak berpengaruh terhadap profitabilitas bank umum syariah.

Return On Asset (ROA) merupakan salah satu rasio profitabilitas yang digunakan untuk mengukur efektivitas perusahaan dalam menghasilkan keuntungan dengan memanfaatkan total yang dimilikinya. Berdasarkan ketentuan Bank Indonesia, maka standar ROA yang baik adalah sekitar $1,5 \%$. Semakin besar ROA menunjukkan kinerja perusahaan semakin baik, karena return semakin besar.

Perhitungan ROA terdiri dari :

1. Menghitung Earning Before Tax (EBT) laba perusahaan (bank) sebelum dikurangi pajak.

2. Menghitung keseluruhan aktiva yang dimiliki oleh bank yang terdiri dari aktiva lancar dan aktiva tetap.

Secara matematis ROA dapat dirumuskan sebagai berikut :

$$
\text { ROA }=\frac{\text { Laba sebelum pajak } \times 100 \%}{\text { total asset }}
$$

Menurut Siamat (1995), rasio profitabilitas digunakan untuk mengukur efektifitas bank dalam memperoleh laba. Disamping dapat dijadikan sebagai ukuran kesehatan keuangan, rasio-rasio profitabilitas ini sangat penting untuk diamati mengingat keuntungan yang memadai diperlukan untuk mempertahankan arus sumber-sumber modal. Teknik analisis profitabilitas ini melibatkan hubungan antara pos-pos tertentu dalam laporan perhitungan laba rugi untuk memperoleh 
ukuran-ukuran yang dapat digunakan sebagai indikator untuk menilai efisiensi dan kemampuan bank dalam memperoleh laba. Oleh karena itu teknik analisis ini disebut juga dengan analisis laporan laba rugi.

Tabel 3.

Pertumbuhan Return on Asset BUS dan UUS

\begin{tabular}{|c|c|c|}
\hline Tahun & ROA & Tingkat Pertumbuhan \\
\hline 2009 & $1,48 \%$ & $4,22 \%$ \\
\hline 2010 & $1,67 \%$ & $12,84 \%$ \\
\hline 2011 & $1,79 \%$ & $7,18 \%$ \\
\hline 2012 & $2,14 \%$ & $19,55 \%$ \\
\hline 2013 & $2,00 \%$ & $-6,54 \%$ \\
\hline 2014 & $0,91 \%$ & $-5,45 \%$ \\
\hline
\end{tabular}

(Statistik Perbankan Syariah, Juni 2015)

Berdasarkan tabel diatas kita dapat menyimpulkan bahwa ROA yang dicapai oleh BUS dan UUS pada tahun 2009 sebesar 1,48\% dan tahun 2010 sebesar 1,67\%, artinya ROA yang diperoleh BUS dan UUS mengalami peningkatan sebesar 12,84\%, sedangkan tahun 2011 ROA mencapai 1,79\% yang berarti mengalami peningkatan sebesar 7,18\%. Sedangkan tahun 2012 mencapai $2,14 \%$ yang berarti mengalami peningkatan $19,55 \%$.

Inflasi oleh para ahli didefinisikan dengan proses kenaikan harga-harga umum barang-barang secara terusmenerus. Ini tidak berarti bahwa harga-harga berbagai macam barang itu naik dengan persentase yang sama. Mungkin dapat terjadi kenaikan tersebut tidaklah bersamaan. Yang penting terjadi kenaikan harga umum barang-barang secara terusmenerus selama satu periode tertentu (Nopirin, 2000: 174).

Tabel 4.

Pertumbuhan inflasi $2009-2014$

\begin{tabular}{|c|c|}
\hline Tahun & Inflasi \\
\hline 2009 & $2,78 \%$ \\
\hline 2010 & $6,96 \%$ \\
\hline 2011 & $3,79 \%$ \\
\hline
\end{tabular}


Pengaruh Variabel Makro Ekonomi terhadap Profitabilitas ...

\begin{tabular}{|c|c|}
\hline 2012 & $4,30 \%$ \\
\hline 2013 & $8,38 \%$ \\
\hline 2014 & $8,36 \%$ \\
\hline
\end{tabular}

http://www.pajak.go.id/content/asumsi-makroekonomi-2009-2012

Inflasi umumnya memberikan dampak yang kurang menguntungkan dalam perekonomian, akan tetapi sebagaimana dalam salah satu prinsip ekonomi bahwa dalam jangka pendek ada trade off antara inflasi dan pengangguran menunjukkan bahwa inflasi dapat menurunkan tinhgkat pengangguran, atau inflasi dapat dijadikan salah satu cara untuk menyeimbangkan perekonomian Negara, dan lain sebagainya.

Penghitungan inflasi dapat dilakukan dengan menghitung nilai indeks harga konsumen yaitu dengan menggunakan rumus:

$$
\text { Inflasi }=\frac{\text { IHKt }- \text { IHKt-1 } \times 100 \%}{\text { IHKt-1 }}
$$

Jika harga-harga mengalami kenaikan, maka orangorang akan cenderung menggunakan uang dalam bentuk cash, untuk digunakan membeli barang-barang guna memenuhi kebutuhan hidupnya, bahkan jika terjadi kenaikan harga yang cukup tinggi akan mendorong orang-orang untuk melakukan rush (mencairkan dananya secara besar-besaran dari bank), orang akan lebih suka menyimpan kekayaannya dalam bentuk asset tak bergerak yang nilainya cenderung meningkat dari tahun ke tahun dan ini dapat menurunkan pendapatan bank yang pada akhirnya dapat menurunkan return on asset bank. Menurut Zeitun (2012), inflasi mempunyai korelasi negative dengan profitabilitas bank syariah.

Produk Domestik Bruto adalah penghitungan yang digunakan oleh suatu negara sebagai ukuran utama bagi aktivitas perekonomian nasionalnya, tetapi pada dasarnya PDB mengukur seluruh volume produksi dari suatu wilayah (negara) secara geografis. Selain itu PDB juga digunakan untuk mengukur nilai pasar dari barang dan jasa akhir yang diproduksi oleh sumber daya yang berada dalam suatu negara selama jangka waktu tertentu, biasanya satu tahun. PDB juga dapat digunakan untuk mempelajari perekonomian dari waktu ke waktu atau untuk membandingkan beberapa perekonomian pada suatu 
saat.

Sukirno (2003) menjelaskan bahwa produk domestik bruto atau GDP merupakan nilai barang dan jasa yang diproduksikan dalam negara dengan menggunakan faktor-faktor produksi yang dimiliki oleh penduduk/perusahaan Negara. PDB hanya mencakup barang dan jasa akhir, yaitu barang dan jasa yang dijual kepada pengguna yang terakhir. Untuk barang dan jasa yang dibeli untuk diproses lagi dan dijual lagi (Barang dan jasa intermediate) tidak dimasukkan dalam PDB untuk menghindari masalah double counting atau penghitungan ganda, yaitu menghitung suatu produk lebih dari satu kali.

Tabel 5.

Laju pertumbuhan PDB 2009 -2014

\begin{tabular}{|c|c|}
\hline Tahun & Laju pertumbuhan \\
\hline 2009 & $4,63 \%$ \\
\hline 2010 & $6,23 \%$ \\
\hline 2011 & $6,49 \%$ \\
\hline 2012 & $6,26 \%$ \\
\hline 2013 & $5,73 \%$ \\
\hline 2014 & $5,06 \%$ \\
\hline
\end{tabular}

(Laporan Bulanan Data Sosial Ekonomi BPS, 2014 : 44)

Tabel diatas menunjukkan bahwa PDB atas dasar harga berlaku pada tahun 2009 mencapai Rp. 5.606 Triliun sedangkan PDB atas dasar harga konstan sebesar Rp. 2.178 Triliun yang berarti tingkat pertumbuhannya mencapai 4,63\%. PDB atas dasar harga berlaku pada tahun 2010 mencapai Rp. 6.446 Triliun sedangkan PDB atas dasar harga konstan sebesar Rp. 2.314 Triliun yang berarti tingkat pertumbuhannya mencapai $6,24 \%$. PDB atas dasar harga berlaku pada tahun 2011 mencapai Rp. 7.419 Triliun sedangkan PDB atas dasar harga konstan sebesar Rp. 2.464 Triliun yang berarti tingkat pertumbuhannya mencapai 6,48\%. PDB atas dasar harga berlaku pada tahun 2012 mencapai Rp. 8.229 Triliun sedangkan PDB atas dasar harga konstan sebesar Rp. 2.618 Triliun yang berarti tingkat pertumbuhannya mencapai $6,25 \%$. 
Kenaikan nilai PDB suatu Negara menunjukkan peningkatan kesejahteraan masyarakatnya, dan ini tentunya akan berdampak pada peningkatan permintaan agregat, dan sudah seharusnya diimbangi dengan pertumbuhan ekonomi di sector riil, peningkatan kesejahteraan masyarakat tentu akan diikuti dengan peningkatan tabungan masyrakat pada bankbank, dan ini akan berpengaruh positif terhadap pendapatan bank, yang akan meningkatkan return on asset pada bank-bank. Menurut Srari (2009), pendapatan nasional berpengaruh positif signifikan terhadap profitabilitas bank syariah.

Variable tingkat suku bunga (BI rate) merupakan alat kebijakan moneter yang digunakan pemerintah untuk mengatur dan mengendalikan stabilitas perekonomian, jika pemerintah ingin mengurangi jumlah uang beredar dan konsumsi yang berhubungan dengan pinjaman bank, maka pemerintah akan menaikkan tingkat suku bunga, dengan adanya suku bunga yang tinggi maka biaya ekonomi (opportunity cost) dari kegiatan konsumsi yang menggunakan pinjaman bank akan semakin mahal, begitu juga sebaliknya.

Pengertian dasar tingkat suku bunga yaitu sebagai harga dari penggunaan uang untuk jangka tertentu. Tingkat bunga mempengaruhi jumlah dana yang ingin dipinjamkan oleh peminjam dan jumlah dana yang akan dipinjamkan oleh pemilik dana. Suatu keadaan dimana Money supply sama dengan demand of funds, maka tingkat bunga berada dalam equilibrium. Pada kenyataanya, tingkat bunga akan secara tetap mengalami perubahan turun naik mencari posisi equilibrium baru. Sudin Haron dalam penelitiannya yang berjudul "Determinants of Islamic Bank Profitability" menemukan bahwa suku bunga berpengaruh negatif dan signifikan terhadap profitabilitas bank syariah (Sultoni, 2014).

Tabel 6.

Data Tingkat Suku Bunga 2009 -2014

\begin{tabular}{|c|c|}
\hline Tahun & Tingkat Suku Bunga \\
\hline 2009 & $7,14 \%$ \\
\hline 2010 & $6,50 \%$ \\
\hline
\end{tabular}




\begin{tabular}{|l|l|}
\hline 2011 & $6,58 \%$ \\
\hline 2012 & $5,77 \%$ \\
\hline 2013 & $6,43 \%$ \\
\hline 2014 & $7,52 \%$ \\
\hline
\end{tabular}

Sumber: www.bi.go.id

Penelitian ini merupakan penelitian kuantitatif deskriptif, penelitian deskriptif merupakan penelitian yang berbasis pada analisis untuk mendiskripsikan factor-faktor yang berhubungan dengan masalah yang sedang diteliti, sedangkan metode kuantitatif merupakan penelitian yang dilakukan untuk mencari variable-variabel yang menjadi objek penelitian, penelitian ini termasuk dalam ruang lingkup penelitian pustaka (Sugiyono, 2013).

Penelitian ini dilakukan pada bank umum syariah di Indonesia selama periode 2009 - 2014, dengan menggunakan teknik purposive sampling, yaitu pengambilan sampel dengan pertimbangan tertentu, dalam penelitian ini menggunakan criteria: (1) Bank yang termasuk bank umum syariah, (2) Bank tersebut beroperasi dan mengeluarkan laporan keuangan triwulanan selama periode penelitian yaitu triwulan I tahun 2009 sampai triwulan IV tahun 2014, berdasarkan kriteria di atas, ada tiga bank yang memenuhi kriteria tersebut yaitu Bank Syariah Mandiri (BSM), Bank Syariah Mega Indonesia (BSMI) dan Bank Rakyat Indonesia Syariah (BRIS).

Berdasarkan data dan analisis yang telah dikemukakan di atas, maka hipotesis null dalam penelitian ini dapat dirumuskan sebagai berikut:

1. Inflasi tidak berpengaruh signifikan terhadap profitabilitas bank syariah di Indonesia.

2. Produk Domestik Bruto tidak berpengaruh signifikan terhadap profitabilitas bank syariah di Indonesia.

3. Tingkat Suku Bunga berpengaruh signifikan terhadap profitabilitas bank syariah di Indonesia.

Analisis yang digunakan dalam penelitian ini adalah analisis regresi linier berganda, dengan menggunakan model regresi sebagai berikut:

$$
\mathrm{ROA}=\alpha+\beta 1 \mathrm{INF}+\beta 2 \mathrm{PDB}+\beta 3 \mathrm{SBI}+\varepsilon
$$


Pengaruh Variabel Makro Ekonomi terhadap Profitabilitas ...

Keterangan:

$\begin{array}{ll}\text { ROA } & : \text { Return on Asset } \\ \alpha & : \text { Konstanta } \\ \beta 1, \beta 2, \beta 3 & : \text { Koefisien regresi } \\ \text { INF } & : \text { Inflasi } \\ \text { PDB } & : \text { Produk Domestik Bruto } \\ \text { SBI } & \text { : Tingkat suku bunga } \\ \varepsilon & : \text { Standar Error }\end{array}$

\section{Uji Normalitas}

Ghozali (2013) menjelaskan Uji normalitas digunakan untuk mengetahui apakah dalam model regresi nilai residual variable dependen dan variable independen terdistribusi secara normal dan independen atau tidak. Untuk menguji normalitas data, peneliti menggunakan uji statistic dengan uji kolmogorvsmirnov, dengan hasil sebagai berikut:

Tabel 7.

Uji Normalitas

\section{One-Sample Kolmogorov-Smirnov Test}

\begin{tabular}{|l|l|r|r|r|r|}
\hline \multicolumn{2}{|c|}{} & Inflasi & \multicolumn{1}{|c|}{ PDB } & Tk Bunga & \multicolumn{1}{c|}{ ROA } \\
\hline $\mathrm{N}$ & 72 & 72 & 72 & 72 \\
\hline \multirow{2}{*}{$\begin{array}{l}\text { Normal } \\
\text { Parameters }\end{array}$} & Mean & 5.5100 & 2042.38 & 6.6596 & 1.6249 \\
\cline { 2 - 6 } & $\begin{array}{l}\text { Std. } \\
\text { Deviation }\end{array}$ & 1.71798 & 421.890 & .69726 & .93786 \\
\hline $\begin{array}{l}\text { Most Extreme } \\
\text { Differences }\end{array}$ & Absolute & .146 & .099 & .157 & .100 \\
\cline { 2 - 6 } & Positive & .146 & .084 & .157 & .100 \\
\cline { 2 - 6 } & Negative & -.076 & -.099 & -.118 & -.075 \\
\hline Kolmogorov-Smirnov Z & 1.238 & .836 & 1.330 & .846 \\
\hline Asymp. Sig. (2-tailed) & .093 & .487 & .058 & .471 \\
\hline \multicolumn{2}{|l|}{ a. Test distribution is Normal. } \\
\hline \multicolumn{2}{|l|}{ b. Calculated from data. } \\
\hline
\end{tabular}

Nilai K-S untuk variable ROA 0.846 dengan probabilitas signifikansi 0.471 yang berada di atas 0.05 , hal itu menunjukkan bahwa hipotesis nol diterima yang berarti variable ROA memiliki distribusi normal, nilai K-S untuk variable Inflasi 1.238 dengan probabilitas signifikansi 0.093 yang berada di atas 0.05 , hal itu 
menunjukkan bahwa hipotesis nol diterima yang berarti variable Inflasi memiliki distribusi normal, Nilai K-S untuk variable PDB 0.836 dengan probabilitas signifikansi 0.487 yang berada di atas 0.05, hal itu menunjukkan bahwa hipotesis nol diterima yang berarti variable PDB memiliki distribusi normal, sedangkan Nilai K-S untuk variable Tk Bunga 1.330 dengan probabilitas signifikansi 0.058 yang berada di atas 0.05 , hal itu menunjukkan bahwa hipotesis nol diterima yang berarti variable Tk Bunga memiliki distribusi normal.

\section{Uji Multikolinieritas}

Tujuan dari uji multikolinieritas adalah untuk mengetahui apakah pada model regresi ditemukan adanya korelasi antar variable independen atau tidak, hasil uj multikolinieritas dapat dilihat nilai tolerance dan nilai VIF, jika nilai tolerance kurang dari 0.1 atau nilai VIF lebih dari 10 berarti terjadi korelasi antar variable independen, hasil uji tersebut dapat dilihat pada tabel berikut ini:

Tabel 8.

Uji Multikolinieritas

\begin{tabular}{|c|c|c|c|}
\hline \multirow{2}{*}{\multicolumn{2}{|c|}{ Model }} & \multicolumn{2}{|c|}{ Collinearity Statistics } \\
\hline & & \multirow[t]{2}{*}{ Tolerance } & \multirow[t]{2}{*}{ VIF } \\
\hline \multirow[t]{4}{*}{1} & (Constant) & & \\
\hline & Inflasi & .578 & 1.729 \\
\hline & PDB & .875 & 1.143 \\
\hline & Tk Bunga & .641 & 1.559 \\
\hline
\end{tabular}

Tabel di atas menunjukkan bahwa nilai tolerance dari variable independen lebih dari 0.1 dan nilai VIF kurang dari 10, dengan demikian tidak terjadi korelasi antar variable independen.

\section{Uji Heteroskesdastisitas}

Uji heteroskedastisitas bertujuan untuk mengetahui apakah dalam model regresi varian residual satu pengamatan ke pengamatan yang lain bersifat konstan (identik) atau tidak, jika bersifat konstan berarti tidak terjadi heteroskedastisitas atau terjadi homoskedastisitas, dan varian residual yang bagus 
Pengaruh Variabel Makro Ekonomi terhadap Profitabilitas ...

adalah yang bersifat konstan.

Hasil uji heteroskedastisitas dapat dilihat melalui uji Glejser, jika hasil uji Glejser memiliki probabilitas signifikan lebih besar dari 0.05 berarti tidak terjadi heteroskedastisitas, hasil uji Glejser dapat dilihat pada tabel berikut ini:

Tabel 9.

Uji Heteroskedastisitas

\begin{tabular}{|c|c|c|c|c|c|c|}
\hline \multirow{2}{*}{\multicolumn{2}{|c|}{ Model }} & \multicolumn{2}{|c|}{$\begin{array}{c}\text { Unstandardized } \\
\text { Coefficients }\end{array}$} & \multirow{2}{*}{$\begin{array}{c}\text { Standardized } \\
\text { Coefficients } \\
\text { Beta } \\
\end{array}$} & \multirow[b]{2}{*}{$t$} & \multirow[b]{2}{*}{ Sig. } \\
\hline & & B & $\begin{array}{l}\text { Std. } \\
\text { Error }\end{array}$ & & & \\
\hline \multirow[t]{4}{*}{1} & (Constant) & -1.118 & .775 & & -1.442 & 154 \\
\hline & Inflasi & -.028 & .052 & -.084 & -.546 & .587 \\
\hline & PDB & .000 & .000 & .172 & 1.379 & .172 \\
\hline & Tk Bunga & .218 & .121 & .263 & 1.805 & .075 \\
\hline
\end{tabular}

Hasil tampilan SPSS secara jelas menunjukkan bahwa tidak ada satupun variable independen yang secara statistic berpengaruh signifikan terhadap variable dependen Absolut residual, ini terlihat dari probabiltas signifikansinya di atas tingkat kepercayaan 0.05, sehingga dapat disimpulkan bahwa model regresi tidak mengandung adanya gangguan heteroskedastisitas.

\section{Uji Autokorelasi}

Uji autokorelasi dilakukan untuk mengetahui apakah dalam model regresi terjadi korelasi antara residual pada periode $t$ dengan residual pada periode $\mathrm{t}-1$ (sebelumnya), dalam penelitian ini uji autokorelasi dilakukan dengan menggunakan uji Durbin-Watson (DW Test), dengan criteria jika nilai DW lebih besar dari batas atas (du) dan kurang dari 4 - du, maka hal itu berarti tidak ada problem autokorelasi dalam model tersebut, hasil uji autokorelasi dapat dilihat pada tabel berikut ini: 
Tabel 10.

Uji Autokorelasi

\begin{tabular}{|l|l|r|l|r|r|}
\hline Model & R & R Square & $\begin{array}{l}\text { Adjusted R } \\
\text { Square }\end{array}$ & $\begin{array}{l}\text { Std Error of } \\
\text { the Estimate }\end{array}$ & $\begin{array}{l}\text { Durbin- } \\
\text { Watson }\end{array}$ \\
\hline 1 & $.474^{\mathrm{a}}$ & .225 & .190 & .47749 & 1.857 \\
\hline a. Predictors: (Constant), LNTkBunga, LNPDB, LNInflasi \\
\hline \multicolumn{6}{|l}{ b. Dependent Variable: ABSRES_2 }
\end{tabular}

Dari tabel di atas, uji Durbin-Watson menghasilkan bahwa nilai DW 1.857 yang berada di atas nilai du 1.71 dan kurang dari 4 - 1.71, hal itu menunjukkan bahwa dalam model regresi tidak terdapat problem autokorelasi atau tidak terjadi korelasi antara residual pada paeriode $t$ dengan residual pada periode t-1 (sebelumnya).

\section{Uji Simultan (Uji F)}

Pengujian ini bertujuan untuk membuktikan apakah variable independen secara simultan berpengaruh terhadap profitabilitas bank syariah, hasil uji $\mathrm{F}$ dapat dilihat dari tingkat signifikansinya, jika tingkat signifikansi kurang dari 0.05 berarti variable independen berpengaruh terhadap variable dependen atau Ho ditolak dan Ha diterima, hasil spss dapat dilihat pada tabel berikut ini:

Tabel 11.

Uji Simultan

\begin{tabular}{|c|c|c|c|c|c|c|}
\hline \multicolumn{7}{|c|}{ ANOVA $^{b}$} \\
\hline \multicolumn{2}{|c|}{ Model } & $\begin{array}{l}\text { Sum of } \\
\text { Squares }\end{array}$ & Df & $\begin{array}{l}\text { Mean } \\
\text { Square }\end{array}$ & $\mathrm{F}$ & Sig. \\
\hline \multirow[t]{3}{*}{1} & Regression & 4.426 & 3 & 1.475 & 6.470 & $.001^{\mathrm{a}}$ \\
\hline & Residual & 15.276 & 67 & .228 & & \\
\hline & Total & 19.702 & 70 & & & \\
\hline \multicolumn{7}{|c|}{ redictors: (Constant), LNTkBunga, LNPDB, LNInflasi } \\
\hline \multicolumn{7}{|c|}{ b. Dependent Variable: ABSRES_2 } \\
\hline
\end{tabular}

Hasil output spss di atas menunjukkan bahwa probabilitas signifikansinya berada di bawah 0.05 yang berarti bahwa variable 
Pengaruh Variabel Makro Ekonomi terhadap Profitabilitas ...

independen (Inflasi, PDB, dan Suku Bunga) secara simultan berpengaruh terhadap variable dependen (Profitabilitas Bank Syariah).

\section{Uji Parsial (Uji t)}

Tabel 12.

\section{Uji Parsial}

\begin{tabular}{|c|c|c|c|c|c|c|}
\hline \multicolumn{7}{|c|}{ Coefficients $^{a}$} \\
\hline \multirow{2}{*}{\multicolumn{2}{|c|}{ Model }} & \multicolumn{2}{|c|}{$\begin{array}{c}\text { Unstandardized } \\
\text { Coefficients }\end{array}$} & \multirow{2}{*}{$\begin{array}{c}\begin{array}{c}\text { Standardized } \\
\text { Coefficients }\end{array} \\
\text { Beta } \\
\end{array}$} & \multirow[b]{2}{*}{$\mathrm{t}$} & \multirow[b]{2}{*}{ Sig. } \\
\hline & & B & $\begin{array}{l}\text { Std. } \\
\text { Error }\end{array}$ & & & \\
\hline \multirow[t]{4}{*}{1} & (Constant) & -10.191 & 2.634 & & -3.868 & .000 \\
\hline & LNInflasi & -.414 & .226 & -.252 & -1.829 & .072 \\
\hline & LNPDB & .903 & .302 & .359 & 2.984 & .004 \\
\hline & LNTkBunga & 2.391 & .663 & .455 & 3.607 & .001 \\
\hline
\end{tabular}

Hasil uji parsial menunjukkan bahwa:

a. Variable Inflasi memiliki probabilitas signifikansi 0.072 yang berada di atas 0.05 , hal ini menunjukkan bahwa variable inflasi tidak berpengaruh signifikan terhadap profitabilitas bank syariah, dan ini sejalan dengan penelitian yang dilakukan Naceur di Tunisia pada periode 1998 - 2000 yang menyimpulkan bahwa inflasi tidak berpengaruh terhadap profitabilitas bank, dengan demikian hipotesis 1 diterima.

b. Variable PDB memiliki probabilitas signifikansi 0.004 yang berada di bawah 0.05 , hal ini menunjukkan bahwa variable PDB berpengaruh signifikan terhadap profitabilitas bank syariah, dan ini sejalan dengan penelitian yang dilakukan Srari yang menyimpulkan bahwa pendapatan nasional berpengaruh terhadap profitabilitas bank, dengan demikian hipotesis 2 diterima.

c. Variable Tingkat Suku Bunga memiliki probabilitas signifikansi 0.001 yang berada di bawah 0.05, hal ini menunjukkan bahwa variable Tingkat Suku Bunga berpengaruh signifikan terhadap profitabilitas bank syariah, dan ini sejalan dengan penelitian yang dilakukan Sudin 


\section{Amirus Sodiq}

Haron yang menyimpulkan bahwa Tingkat Suku Bunga berpengaruh terhadap profitabilitas bank, dengan demikian hipotesis 1 diterima

\section{PENUTUP}

Berdasarkan penelitian di atas, maka dapat ditarik kesimpulan bahwa Variable Inflasi memiliki probabilitas signifikansi 0.072 yang berada di atas 0.05 , hal ini menunjukkan bahwa variable inflasi tidak berpengaruh signifikan terhadap profitabilitas bank syariah, dan ini sejalan dengan penelitian yang dilakukan Naceur di Tunisia pada periode 1998 - 2000 yang menyimpulkan bahwa inflasi tidak berpengaruh terhadap profitabilitas bank.

Variable PDB memiliki probabilitas signifikansi 0.004 yang berada di bawah 0.05 , hal ini menunjukkan bahwa variable PDB berpengaruh signifikan terhadap profitabilitas bank syariah, dan ini sejalan dengan penelitian yang dilakukan Srari yang menyimpulkan bahwa pendapatan nasional berpengaruh terhadap profitabilitas bank.

Variable Tingkat Suku Bunga memiliki probabilitas signifikansi 0.001 yang berada di bawah 0.05 , hal ini menunjukkan bahwa variable Tingkat Suku Bunga berpengaruh signifikan terhadap profitabilitas bank syariah, dan ini sejalan dengan penelitian yang dilakukan Sudin Haron yang menyimpulkan bahwa Tingkat Suku Bunga berpengaruh terhadap profitabilitas bank. 
Pengaruh Variabel Makro Ekonomi terhadap Profitabilitas ...

\section{DAFTAR PUSTAKA}

Anto dan M. Ghofur Wibowo, 2012, Faktor-faktor Penentu Tingkat Profitabilitas Bank Umum Syariah di Indonesia, Jurnal Ekonomi Islam La_Riba, Vol. IV, No. 2, Desember.

Bachdar, Saviq, 2015, Kredit Macet Bank Syariah Melambung Tinggi, http://marketeers.com/article/kredit-macetbank-syariah-melambung-tinggi.html

Bank Indonesia, 2012, Outlook Perbankan Syariah Indonesia.

Bank Indonesia, 2015, Statistik Perbankan Syariah.

Bashir, A. 2000, "Determinants of profitability and rates of return margins in Islamic banks: some evidence from the Middle East" Grambling State University Mimeo.

Fauziah, Ravika, 2011, Analisis Pengaruh Inflasi Terhadap Tingkat Profitabilitas Bank Muamalat Indonesia dan Bank Central Asia (BCA) Tahun 2007-2011, Surabaya: Universitas Negeri Surabaya.

Ghozali, Imam, 2013, Aplikasi Analisis Multivariate dengan Program IBM SPSS 21 Update PLS Regresi, Semarang: BP UNDIP.

Haron, Sudin, 2004 "Determinants of Islamic Bank Profitability" Global Journal of Finance and Economics, USA, Vol 1, No 1, Maret 2004

Irfany, Robby, 2015, Mengapa Ekonomi Indonesia Lesu? Ini Penjelasan Menkeu, Tempo.co.Jakarta.

Naceur, Samy, 2003, The Determinants of The Tunisian Banking Industry Profitability: Panel Evidence, ERF Research Fellow Department of Finance Universite Libre de Tunis, October. 
Nopirin, 2000, Pengantar Ilmu Ekonomi Makro Dan Mikro, Ed. 1, Yogyakarta: BPFE Universitas Gadjah Mada.

Sahara, Ayu Yanita, 2013, Analisis Pengaruh Inflasi, Suku Bunga BI dan Produk Domestic Bruto Terhadap Return On Asset (ROA) Bank Syariah di Indonesia, Jurnal Ilmu Manajemen, Vol. 1, No. 1, Januari 2013.

Siamat, Dahlan. 2005. Manajemen Lembaga keuangan, Ed. 4, Jakarta: BP Fakultas Ekonomi Universitas Indonesia.

Srairi, Samir Abderrazek. 2009. "Factor Influencing the Profitability of Conventional and Islamic Commercial Banks in GCC Countries", Review of Islamic Economics, Vol. 13, No. 1, 2009.

Stiawan, Adi, 2009, Analisis Pengaruh Faktor Makro Ekonomi, Pangsa Pasar dan Karakteristik Bank Terhadap Profitabilitas Bank Syariah (Studi Pada Bank Syariah Periode 2005 - 2008), Tesis MM UNDIP.

Sugiyono, 2013, Metode Penelitian Kuantitatif, Kualitatif dan R \& D, Bandung: Alfabeta.

Sukirno, Sadono, 2003, Teori Pengantar Ekonomi Makro, Jakarta: PT Raja Grafindo Persada.

Sultoni, Hasan, 2014, Faktor-faktor Penentu Tingkat Profitabilitas Bank Umum Syariah di Indonesia, Eksyar, Volume 01, Nomor 01, Maret 2014: 042-055.

Wahidudin, Ahmad Nazri and Ulaganathan Subramaniam and Pengiran. Abd Mutalib Pg. Kamaluddin, 2012, Determinents of profitability a comparative analysis of islamic banks and conventional banks in ASEAN countries, 2ndInternational Conference on Accounting, Business and Economics (ICABEC2012) 10-11th November 2012, MS Garden Hotel, Kuantan Pahang, Malaysia. 
Pengaruh Variabel Makro Ekonomi terhadap Profitabilitas ...

Zeitun, Rami, 2012, Determinants of Islamic and Conventional Banks Performance in GCC Countries Using Panel Data Analysis, Global Economy a nd Finance Journal Vol. 5. No.1. March 2012. Pp. $53-72$.

www.bi.go.id

www.brisyariah.co.id

www.megasyariah.co.id

www.syariahmandiri.co.id

http://www.pajak.go.id/content/asumsi-makroekonomi-2009-2012 